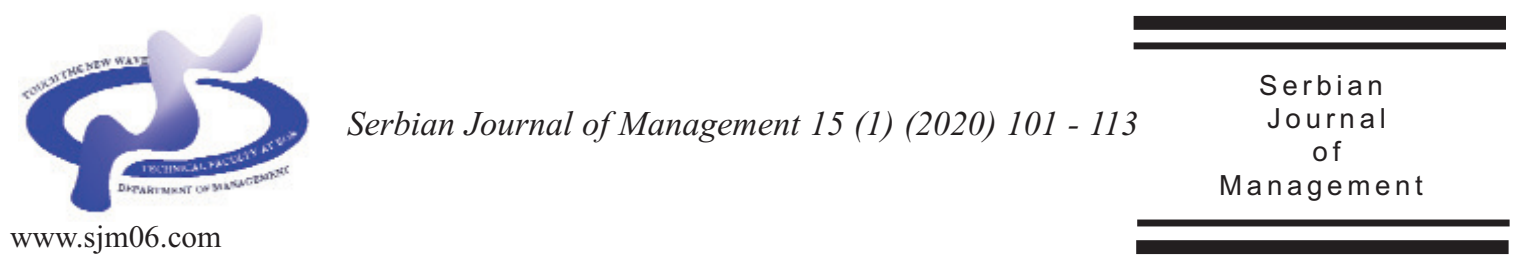

\title{
TRUANCY AND JOB SATISFACTION AMONG DUAL CAREER COUPLES TOWARDS ORGANIZATIONAL SPONSORED DAY CARE AMENITIES IN DEVELOPING NATION
}

\author{
Omvir Gautam*and Pooja Agrawal \\ Vishwakarma University, IndiaFaculty of Commerce and Management \\ Vishwakarma University, Pune 411048, Maharashtra, India
}

(Recieved 27 October 2017; accepted 10 October 2019)

\begin{abstract}
The prevalent concern in the present work environment is daycare amenities for dual career couples in developing nations like India. It plays a significant role in improvising the employeeemployer relationship. This study identifies the pivotal factors like truancy and job satisfaction among dual career couples towards organizational sponsored daycare amenities. Moreover, role of organizational sponsored daycare amenities has been examined along with moderators like gender and numbers of children A descriptive research design was employed along with the usage of a selfadministrated questionnaire to a sample of 197 employees from two states of Punjab i.e Amritsar and Punjab, India; to assess the moderator role of gender and number of children towards the organizationally sponsored daycare amenities. Organizational sponsored daycare amenities towards truancy rate and job satisfaction were found significant. Organizational sponsored daycare amenities are positively new to employees and even for employers in developing nations like India. Future studies may thrust on implications of organizational sponsored daycare amenities in the nourishment of organizational existence for longer eternity.
\end{abstract}

Keywords: daycare, organizational sponsored, job satisfaction, gender, moderator, number of child, truancy

\section{INTRODUCTION}

Female played a critical role in development of any nation's economy in last few decades. Some organizations like
International Labour Organization (ILO), Indian Express and National Survey Reports etc. highlighted that the ratio of working females sensationally expanded in the organizations. Numerous researchers did

\footnotetext{
* Corresponding author: dromvirgautam1986@gmail.com
}

DOI: $10.5937 / \operatorname{sjm} 15-15490$ 
their analysis to understand the reasons that why are the number of working females increasing in the Indian society. Researchers identified manifold reasons like; Firstly, females are more educated as compared to earlier time because of this they want to become self-dependent for their livelihood. Secondly, families are increasing their living standards as compared to the previous time because of this the income of a male person is not enough for their livelihood. To fulfill their families' requirements and to provide a wealthy life to their children the scenario of dual career couples are increasing in Indian society. Thirdly, like abroad in India the couples' separation rate is also expanding which increases the number of working females to be acted an independent and a single parent.

On the other side, various research reports are highlighted the immeasurable reasons that females are also doing pull out or left their employment. As indicated by ILO report that the core reason is inequality in employment opportunities. It implies that equivalent employments are not accessible for females as like males. In India, there is exceptionally less number of enterprises which are providing a platform for females act as a workforce. Furthermore, females are also facing an issue of abusive, bullying and provocation at work environment in developing nation like India. As Indian government is concerned with sexual harassment problem, a legal provision passed on this in 2013. According to this law enterprises where 10 or more than 10 employees are employing, grievance committee have been settled to investigate all complaints. Hester and Dickerson (1984) identified the dearth of Dual Career Couple (DCC) need of job. It could be as the living standards in society increased in last couple of years. The organization is providing facility to their employee where they can feel comfortable and not to worry for their children's care. Working couples get absent and took unplanned leave due to which their company feel reluctant in growth perspective. So, this research is an initiative or an attempt in direction of examining the relationship between OSDCA, TR and JS.

\section{LITERATURE REVIEW; HYPOTHESES SYNTHESES AND CONCEPTUAL MODEL}

\subsection{Dual Career Couples (DCC) and Organizational Sponsored Day Care Amenities (OSDCA)}

For organizations it is mandatory they provide organizational sponsored day care facility in order to achieve desirable benefits from their workforce like motivated staff, increase in sales or inception of new ideas etc. Researchers like (Hester \& Dickerson, 1984; Rapoport \& Rapoport, 1969) defined dual career couples as a relationship between two persons those who are committed to one another and having similar accountabilities towards their profession, employment as well as their family. Organizational sponsored day care amenities reflect a way that enterprises are taking some initiatives to satisfy the need of workers associated with their child care. A very few enterprises disburse a limited amount of money to offer this amenity to their staff as a welfare scheme. A research survey done by Jawaharlal Nehru College (JNU), fewer than 20 percent enterprises are following this provision in New-Delhi. Third and preeminent reason is the females' consideration for their kids. 
Present research dissected that how organizational sponsored day care amenities is affecting dual career couples' truancy rate and job satisfaction level. The truancy rate and job satisfaction has been considered as criterion while ESCC has predictor one. In developing nation context like India, DCC has shown greater inception as compared to developed nations. This study also catered the impact of gender on employee's truancy rate to know their pattern for attendance rate (truancy) in organization because of child's care concerns as their main objective due to which organization suffered with human loss.

Workforce who have kids below age of six are taking their impromptu leave conducted by AT \&T in Indian parlance. It was also noticed that they deteriorate their productivity and also shift their work orientation towards their kids and spending their lot of time in kid care issues especially sickness. In addition to this another survey revealed that 65 percent parents are coming late additionally leaving early their jobs because of child-care related issues. The hypothesis developed is:

$\mathbf{H}_{\mathbf{0 1}}$ : There is no existence of DCC and OSDCA

\subsection{Truancy (TR)}

Truancy is an activity which indicated that employees are consistently and regularly remain absents from their scheduled work. Enormous researchers postulated that employees' truancy of is a contemporary issue for the organization. Moreover, different researchers (Steers \& Rhodes, 1978; Meisenheimer, 1990; Geurts et al., 2000; Barmby et al., 2002; Johns, 2003; Gimeno et al., 2004; Barham \& Begun, 2005
; Leaker, 2008; Agrawal \& Gautam, 2018) highlighted that truancy rate among the female staff were more as compared to male staff. Likewise, a research survey in U.S. unfolds this fact that truancy rate of female staff was 58 percent higher when contrasted with male staff. The method of reasoning was presumed that females were indicating higher truancy rate as a result of family obligations like kids' care as well as elder care. Steers and Rhodes (1978) posited that as the family size and responsibilities increased then the truancy rate among female employees also increased. Keith \& Schafer (1980) indicated that as the number of children increased in the family then the improper balanced arisen in family and work. They also concluded that pressure for quality work life balance was more in working married women as compared to unmarried working women. Miller (1984) supported the fact that unmarried female employees were revealing less truancy rate as compared to the married female employees. Additionally, Barmby et al., (2002) underlined the fact that married working females' revealed greater rate of absenteeism when contrasted with unmarried working females. The reasoning of this finding was that married females had higher affectability towards their family accountabilities. Furthermore, the discoveries of Barham and Begum (2005) uncovered a huge distinction between the truancy rate of females those were having self-dependent kids and not having selfdependents kids. The hypothesis developed is:

$\mathbf{H}_{\mathbf{0 2}}$ : There is no reciprocal relationship of OSDCA with Truancy 


\subsection{Job Satisfaction}

Job satisfaction is a reflection of a pleasurable emotion and feeling of accomplishment driven by an individual from their job. It is a vivid term in psychology and research. Miller (1984) discovered that female workforce who was having children demonstrated high truancy as well as lower job satisfaction when contrasted with male workforce. Based on discoveries, it was inferred that organizational sponsored daycare amenities help in crumble staffs' truancy rate and expands staffs' efficiency and employment satisfaction. Furthermore, Youngblood. and Cook, (1984) diagnosed that organizational sponsored day care amenities help to enhance the commitment and satisfaction level of the workforce as well as decay the truancy rate. Additionally, Eisenberger et al. (1990) highlighted this fact that at whatever point staff recognizes themselves as worthy part of the organization then at that point there was a positive and critical effect of it on their regularity, involvement, fulfillment and efficiency. Similarly, Kossek and Nichol (1992) unfold this fact that organizational sponsored day care amenities significant positively affect the employees' attitude, satisfaction level. It was also diagnosed that these amenities significant negatively associated with truancy and turnover rate of the employees. A survey conducted by Cornell University in US revealed in increased satisfaction level in employer and also reduced the truancy rate of employees by $20-30$ percent and turnover rate by $37-60$ percent respectively. The hypothesis developed is:

$\mathbf{H}_{\mathbf{0 3}}$ : There is no impact of OSDCA on Job satisfaction
As Agrawal and Gautam (2018) found that the relationship amongst absenteeism and employer supported child care facility was found inverse relationship and significant but in what magnitude the gender plays a role was not ascertained. So more prepositions on two categorical variables such as gender and number of child is considered.

\subsection{Gender and Number of Children}

At last but not least gender has been termed as moderator variable, supported by authors Steers and Rhodes (1978), and Keith and Schafer (1980) revealed that gender had a significant impact on the absenteeism rate (truancy) of employees. Furthermore, analysis indicated that females were showing more absenteeism rate as compared to males. This directed to the researcher in order to consider the relevance of gender as a mediator for the present study. Number of child/ren was study by Simons et al. (1992), Amato (1990), and NICHD Early Child Care Research Network, (2002) established a relation with truancy and developmental outcomes of the study. The hypotheses developed as gender and number of child as moderator areas:

$\mathbf{H}_{\mathbf{0 4 a}}$ : There is no significant impact of OSDCA on the employees' truancy gender as moderator.

$\mathbf{H}_{\mathbf{0 4 b}}$ : There is no significant impact of OSDCA on the employees' Job Satisfaction gender ad moderator.

$\mathbf{H}_{\mathbf{0 5}} \mathbf{a}$ : There is no significant impact of OSDCA on the employees' truancy Number of child as moderator. 


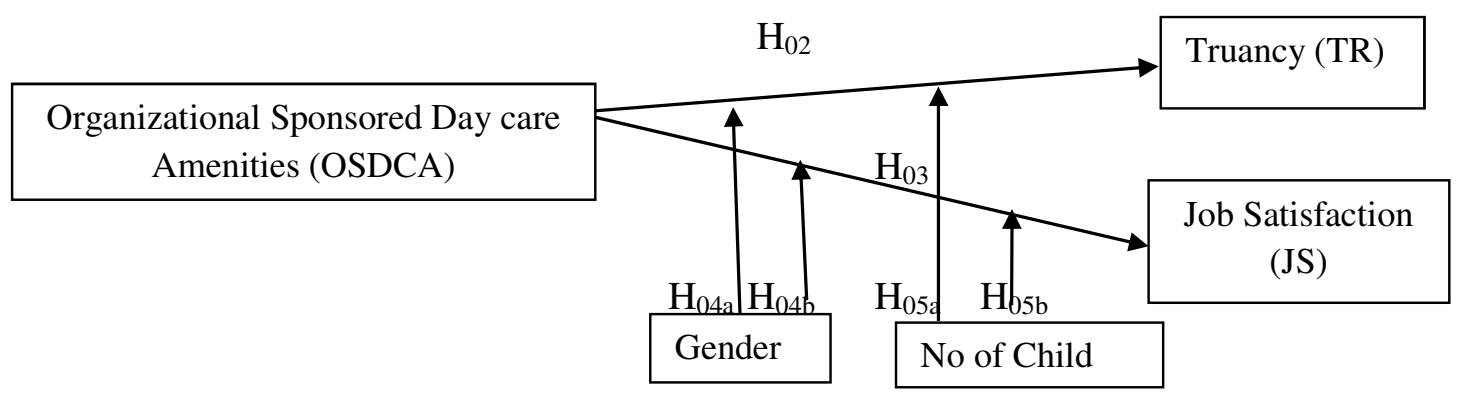

Figure 1. Hypothesis model

$\mathbf{H}_{\mathbf{0 5}}$ : There is no significant impact of OSDCA on the Job Satisfaction Number of child as moderator.

The conceptual framework was shown in Figure 1. The next section deals with the methodology aspect of current paper.

\section{METHODOLOGY}

This study was a descriptive and cross sectional carried in between June 2017 to August 2017 by employing a self-structured questionnaire. A sample of 197 employees was tapped randomly from Amritsar and Jalandhar city of Punjab, India. This survey tool was used to gather the data from employees who were termed as Dual Career Couples (DCC). The scale used for this study was relied from different researchers' statements from previous literature like ( $\mathrm{Su}$ Kumar, 2009). A 5 point-Likert scale was considered for designing the survey tool, 1 shows the least agreed option and 5 indicate the most agreed option. Pre-testing was done on a small sample of 32 dual career couples (DCC) working in organizations to assured the validity and reliability concern of the research tool used for the study. Data collection was done by adopting nondisguised questionnaire from two major cities of Punjab like Amritsar and Jalandhar.
The employees were considered as respondent only when they were fulfilling the criteria; married and at least had one child. Rationale applied to assess the dearth of organizational sponsored day care amenities at work stations. As demographical profiles of the respondents is concern, only gender and Number of child/ren are catered as useful descriptive for males $(n=124)$ constituting 63.19 percent while for female $(n=73)$ constituting 36.81 percent out of final sample of 197 valid and usable questionnaires. The other useful demographical information is pertained by number of child/rens, couples having one child is $(n=120) 60.6$ percent and couples having more than one child is $39.4(n=67)$ percent.

\section{RESULTS AND DISCUSSION}

The DCC and OSDCA was found moderately correlated (Hair et al., 2010) and significant $(\mathrm{r}=0.567)$ at 5 percent of significance level. So, H01 is rejected and hence alternate hypothesis established that there is a relationship between DCC and OSDCA.

\subsection{Results of Measurement Model}

To ensure validity of the scale used for the 
study, a confirmatory factor analysis (CFA) was carried out on collected data. There were number of model fit indices tested such as CMIN (chi-square minimum/ degree of freedom), normed fit indices (NFI), GFI (Goodness of fit index), CFI (comparative fit index), AGFI (Adjusted Goodness of fit index) and Root Mean Square of Approximation (RMSEA).

\subsubsection{Scale Reliability and Convergent validity}

Cronbach alpha $(\alpha)$ and composite reliability $(\mathrm{CR})$ for each dimension used in the current study (Table 1) were two important and popular measure of internal consistency. It was found that both of these internal consistency were more than the suggested acceptable limit of 0.70 (Nunnally,
1978; Hair et al, 2010) as mentioned in Table 1. The measure CR was also significant and established as its all values were more than 0.50. Interestingly, it is more than AVE (average variance extracted) and ASV (average shared variance). Principal component analysis (PCA) method was performed and a very high inter-item correlations within each of the three dimensions used in this study, showing reliable and sufficient concern of convergent validity.

\subsubsection{Discriminant Validity}

The average variance extracted (AVE) by a construct must be more than the variances it shares with other constructs (Fornell \& Larcker, 1981; Bagozzi et al., 1991; Hair et al,2010) for establishment of discriminant

Table 1. Construct reliability with its psychometric properties

\begin{tabular}{|c|c|c|c|c|c|}
\hline Construct & Factor loadings & $\mathbf{C R}$ & AVE & Cronbach $(\alpha)$ & ASV \\
\hline \multirow{5}{*}{$\begin{array}{l}\text { Organizational Sponsored Child-Care } \\
\text { Amenities (OSDCA) }\end{array}$} & 0.799 & \multirow{5}{*}{0.891} & \multirow{5}{*}{0.793} & \multirow{5}{*}{0.795} & \multirow{5}{*}{0.184} \\
\hline & 0.897 & & & & \\
\hline & 0.776 & & & & \\
\hline & 0.792 & & & & \\
\hline & 0.702 & & & & \\
\hline \multirow{4}{*}{ Truancy(TR) } & 0.904 & \multirow{4}{*}{0.884} & \multirow{4}{*}{0.787} & \multirow{4}{*}{0.897} & \multirow{4}{*}{0.164} \\
\hline & 0.895 & & & & \\
\hline & 0.856 & & & & \\
\hline & 0.853 & & & & \\
\hline \multirow{5}{*}{ Job satisfaction (JS) } & 0.798 & \multirow{5}{*}{0.901} & \multirow{5}{*}{0.713} & \multirow{5}{*}{0.907} & \multirow{5}{*}{0.197} \\
\hline & 0.813 & & & & \\
\hline & 0.819 & & & & \\
\hline & 0.900 & & & & \\
\hline & 0.877 & & & & \\
\hline
\end{tabular}

Table 2. Discriminant and Convergent Validity of Survey tool

\begin{tabular}{lccc}
\hline & (OSDCA) & (TR) & (JS) \\
\hline (OSDCA) & 0.787 & & \\
(TR) & 0.475 & 0.757 & \\
$($ JS $)$ & 0.322 & 0.584 & 0.810 \\
\hline
\end{tabular}

Note: OSDCA- Organizational Sponsored Day care Amenities, TR- Truancy, JS-Job Satisfaction 
validity. Table 2 , the diagonal measures shows the square root of AVE and all other non-diagonal measure posits the correlations among constructs i.e. the shared variance. Since, in this study all non-diagonal values are lower than diagonal values showing the AVE for each construct is more than shared variation with respect to other constructs. The present evidence urges scale validation for the current used and has sufficient discriminant validity.

\subsection{Testing Results of SEM}

To test the proposed model, SEM approach was employed and the model showed a good fit. All measures were found to consistent with acceptable values as shown in Table 3. The model indices considered for the current study were found to be under prescribed limits (Hair et al, 2010). The model fit (CMIN/DF) chi square minimum/degrees of freedom was shown to be 1.988. This value was lower than the acceptable value of 3 (Andy, P. Field, 2005). Other measures such as CFI, GFI, NFI and TLI were $0.912,0.921,0.932$ and 0.947 respectively. All values were found justifiable and above acceptable value of 0.900 (Hair et al, 2010). The RMSEA value was 0.041 which was less than acceptable value of 0.05 . All the model indices supported for overall model fitness of the conceptual framework. All hypotheses identifying direct associationship were established at $p=.05$ and were supported by model mentioned in the Figure 2. The statistical and path coefficients are mentioned in Table 4.

Organizational Sponsored Day Care Amenities (OSDCA) was found significant with respect to Truancy (T) with $b=0.399$, $p<.05$. While, Job Satisfaction (JS) found to be most significant with (OSDCA) with $b=0.468, p<.05$.

Table 3. Model fit indices summary of SEM

\begin{tabular}{llllll}
\hline Model & NPAR & CMIN & DF & P & CMIN/DF \\
\hline Default & 87 & 713.52 & 357 & 0.000 & 1.998 \\
Saturated & 454 & 0.000 & 0 & & 4.175 \\
Independence & 27 & 1987.457 & 476 & 0.000 & \\
$\left(\chi^{2} / d f\right)$ CMIN/DF must be less than 3, here it is 1.988 & & & & RMSEA \\
Model & CFI & GFI & NFI Delta 1 & TLI rho2 & 0.041 \\
Default Model & 0.912 & 0.921 & 0.932 & 0.947 & \\
\hline $\begin{array}{l}\text { Note: CFI- Comparative Fit Index, GFI-Comparative Fit Index, NFI-Normed Fit Index, TLI-Tucker-Lewis index, RMSEA-Root Mean Square } \\
\text { Error of Approximation. }\end{array}$ & & &
\end{tabular}

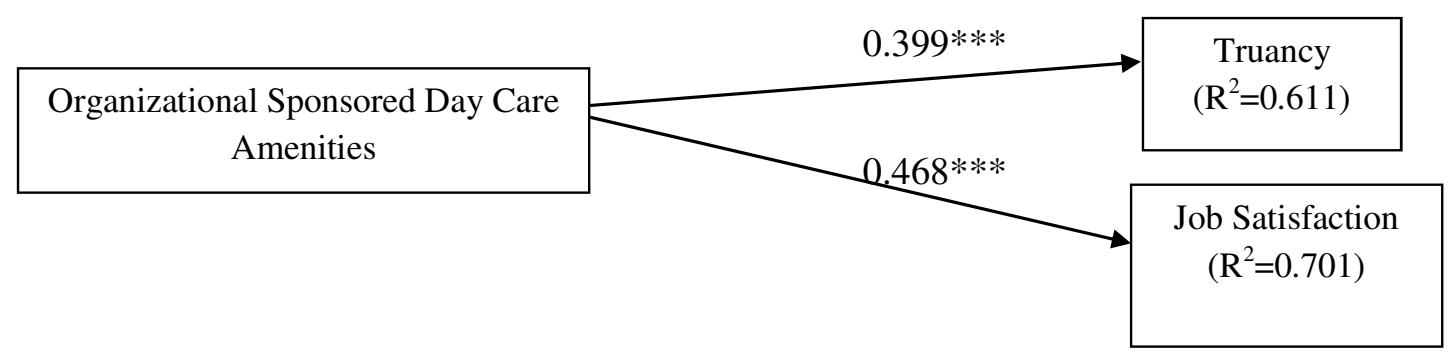

Figure 2. Structural model 


\subsection{Moderation analysis results}

Moderation analysis was performed employing AMOS 21.0 by imbibing structural equation models using hypothesized model on two dimensions of each of the moderator. The current study relied on gender (Male and Female) and Number of Child (one child and two and above child). Both categories of two moderators, the structural model were found pertinent and well fitted with all overall fit indices (CMIN/DF less than 3, AGFI, GFI, CFI above threshold limit of 0.900 and RMSEA $<0.05)$ within acceptable limits. The critical ratio (C.R.) (Greater than \pm 1.96 , $p<0.05$ ) test used to compare the associationship among constructs of the hypothesized model, the regression weights for respective two categories of a moderator.

\subsubsection{Gender as Moderator}

The impact of predictor variable OSDCA on TR was more significant (path estimates) for female $(b=0.564)$ than male $(b=0.497)$ with different and significant with $\mathrm{Z}$ score $=2.341$ being greater than 1.96 (Table 5). So $\mathrm{H}_{1 \mathrm{a}}$ was supported. Our $\mathrm{H}_{2 \mathrm{a}}$ was also supported with impact of OSDCA on JS on being stronger for female as compared to male with significant different $\mathrm{Z}$ score of 2.817 which is greater than 1.96. So, all hypotheses $\mathrm{H}_{4 \mathrm{a}}, \mathrm{H}_{4 \mathrm{~b}}$ were found supported.

\subsubsection{Number of child as Moderator}

The impact of predictor variable OSDCA on TR was more significant (path estimates) for coups having more than 1 child ( $b=0.465)$ than having 1 child $(b=0.435)$ with

Table 4. Hypotheses testing and path coefficients

\begin{tabular}{cccccc}
\hline Hypothesis & Estimate & S.E. & t-value & p-value & Decision \\
\hline TR $\leftarrow$ OSDCA & 0.399 & 0.096 & 8.749 & $* * *$ & Supported \\
JS $\leftarrow$ OSDCA & 0.468 & 0.038 & 11.352 & $* * *$ & Supported \\
\hline
\end{tabular}

Table 5. Gender as a moderator

\begin{tabular}{|c|c|c|c|c|c|}
\hline \multicolumn{3}{|c|}{ Male } & \multicolumn{3}{|c|}{ Female } \\
\hline Construct relationships & Estimate & Sig. level (P) & Estimate & Sig. level (P) & Z-score \\
\hline TR $\leftarrow$ OSDCA & 0.497 & 0.001 & 0.564 & 0.000 & 2.341 \\
\hline $\mathrm{JS} \leftarrow$ OSDCA & 0.301 & 0.000 & 0.204 & 0.000 & 2.817 \\
\hline \multicolumn{3}{|c|}{$\begin{array}{l}\text { Model 1- AMOS-SEM for Male } \\
\text { CMIN/DF-1.972, GFI-0.910,AGFI-0.908, } \\
\text { CFI-0.912 \& RMSEA0.038 }\end{array}$} & \multicolumn{3}{|c|}{$\begin{array}{l}\text { Model 2- AMOS-SEM for Female } \\
\text { CMIN/DF-2.117, GFI-0.913,AGFI- 0.906, } \\
\text { CFI-0.914 \& RMSEA-0.033 }\end{array}$} \\
\hline
\end{tabular}

Table 6. Number of child as a moderator

\begin{tabular}{|c|c|c|c|c|c|}
\hline \multicolumn{3}{|c|}{ Having 1 child } & \multicolumn{3}{|c|}{ More than 1 child } \\
\hline Construct relationships & Estimate & Sig. level $(\mathrm{P})$ & Estimate & Sig. level (P) & Z-score \\
\hline TR $\leftarrow$ OSDCA & 0.435 & 0.001 & 0.465 & 0.000 & 1.989 \\
\hline $\mathrm{JS} \leftarrow$ OSDCA & 0.375 & 0.000 & 0.289 & 0.002 & 2.003 \\
\hline \multicolumn{3}{|c|}{$\begin{array}{l}\text { Model 1- AMOS-SEM for having one child } \\
\text { CMIN/DF-2.172, GFI-0.911,AGFI- } 0.918 \text {, } \\
\text { CFI-0.919, RMSEA-0.031 }\end{array}$} & \multicolumn{3}{|c|}{$\begin{array}{l}\text { Model 2- AMOS-SEM for having more than one child } \\
\text { CMIN/DF- } 2.417 \text {, GFI-0.914,AGFI- } 0.907 \text {, } \\
\text { CFI-0.917, RMSEA-0.027 }\end{array}$} \\
\hline
\end{tabular}


different and significant with $\mathrm{Z}$ score $=1.989$ being greater than 1.96 (Table 6). $\mathrm{So}_{4 \mathrm{a}}$ was supported. Our $\mathrm{H}_{4 b}$ was also supported with impact of OSDCA on JS on being stronger for employees having 1 child $(b=0.375)$ as compared to employees having more than 1 child ( $b=0.289)$ with significant different $Z$ score of 2.003 which is greater than 1.96 . So, all hypotheses $\mathrm{H}_{5 \mathrm{a}}, \mathrm{H}_{5 \mathrm{~b}}$ were found supported.

\section{DISCUSSION}

The concept of day care burnt out exceptionally for Dual career couples (DCC) in today's turbulent environment. The pressure of quantifying the target is on the rise along with other accountabilities of the employees. The current present article is an attempt to fill the bridge between the employees abd the organizational sponsored day care amenities. Researchers Perry, 1978 and Farrel (1980) for females were perceived as a main impediment of their life. The primitive purpose of this article was to assess the relationship between OSDCA with respect to TR and JS, by incorporating the conceptual model. Further, it was analyzed that OSDCA was significant with TR and JS. Table 6, shows that moderator OSDCA as a main dimension Truancy (TR) with its beta value ( $b=0.435)$ followed by Job satisfaction (JS) with $(b=0.325)$ for one child as moderator significantly as expected. Most of the results were on anticipated lines and therefore all hypotheses were conceptualized. It was also assessed that (OSDCA) significantly related with TR and JS. Gullekson et al. (2014) proved that organizations providing child-care facilities diminished the rate of employees' absentees.
This finding is also supported by the other authors like Goff et al., (1990), Kossek and Nichol (1992), Ezra and Deckman (1996), and Agrawal and Gautam (2018).

A report by Cornell University in 2004 that those employers provided employees children in terms of child-care facility like education support, fees reimbursement increased their efficiency, morale, satisfaction level and ultimately reducing the absenteeism among the employees. Goff et al. (1990), Kossek and Nichol (1992), and Ezra and Deckman (1996) concluded that employers' sponsored child-care amenities positively affected job satisfaction but study by Ratnasingam et al, (2012) point of view for this aspect was negatively associated for job satisfaction. Furthermore, two categorical variables namely gender and number of child was moderated the relationship between OSDCA with TR and OSDCA provided significant effects. It was found that impact of OSDCA on TR was stronger for both genders, while JS was lower for female as compared to male. Similarly, TR was lower as in couples having one child with respect to more than one child, but it was inversely associated for job satisfaction.

\section{LIMITATIONS AND FUTURE SCOPE}

The first limitation is that the respondents are taken as dual career couples, which not truly represent the demographical attribute for a developing nation like India where working couple ratio is not as high of developed nation. Second, limitation is in the form of sample size it may not appropriate for generalization of the results. As in spite of these two limitation of the study still have futuristic implications for human resource 
managers or organizations in terms of identify the utility and importance of these two terms such absenteeism and job satisfaction. In future HR practices may be adopted by managers certainly to eradicate the problem of truancy and will sustain their staff for long term sustenance. Further, scope may be including work engagement and family support for better validity and reliability concerns. Still many organizations have not understood and adopted these two factors in the manner as expected. Lastly, researchers must incorporate more dimensions to make present conceptual model as more robust by imbibing more constructs like family support, work engagement etc.

\section{CONCLUSION}

This study undergoes the vital issue of job satisfaction and absenteeism as a prevalent concern in today's modern organization. The study demonstrates female has changed. Females are performing dual role as homemaker and organization maker. Perry (1978) and Farrel (1980) found thrust on sponsored child care facilities, Our finding from present study also explores the dearth of organizational sponsored day care amenities and consistent with the findings of Amato, (1990), Simons et al. (1992), and Agrawal and Gautam (2018) . The moderation results in terms of gender are still significant and consistent to finding of various previous researches (Goff et al., 1990; Kossek \& Nichol, 1992; Gullekson et al., 2014).

Organizational sponsored day-care amenities (OSDCA) have significant effect over job Satisfaction of employees (Goff et al., 1990; Kossek \& Nichol, 1992; Ezra \&
Deckman 1996; Gullekson et al., 2014; Agrawal \& Gautam, 2018). Furthermore, it has been explored that female are more indulged in truancy and less satisfied with their job satisfaction in developing nations like India because of lack of family support. This finding is quite relevant to previous author's opinions (Steers \& Rhodes, 1978; Johns, 2003; Barham \& Begum, 2005; Agrawal \& Gautam, 2018) shows on lower satisfaction level with in their work place. In order to uplift the satisfaction level and lowers the absenteeism amongst the employees than the organization has to employ more sophisticated day care amenities and incentives to their existing employees.

\section{References}

Agrawal, P., \& Gautam, O. (2018).Truancy and Job Satisfaction towards Sponsored Child Care Facility in India. Prabandhan: Indian Journal of Management, $11(7), 23-35$.

Amato, P.R. (1990). Dimensions of the Family Environment as Perceived by Children: A Multidimensional Scaling Analysis, Journal of Marriage and the Family, 52 (3), 613-620.

Bagozzi, R. P., Yi, Y., \& Phillips, L. W. (1991). Assessing construct validity in organizational research. Administrative science quarterly, 421-458.

Barham, C., \& Begum, N. (2005). Sickness Absence from Work in the UK. Labour Market Trends, Office for National Statistics, 4, 149-158.

Barmby, T.A., Ercolani, M.G., \& Treble, J.G. (2002). Sickness absence: An International Comparison. The Economic Journal, 112 (480), 315-331. 


\title{
ИЗОСТАЈАЊЕ И ЗАДОВОЉСТВО ПОСЛОМ МЕЪУ ПАРОВИМА СА ДУАЛНИМ КАРИЈЕРАМА У ОДНОСУ НА ПОГОДНОСТИ ОРГАНИЗАЦИЈСКИ СПОНЗОРИСАНИХ ОБДАНИШТА У ЗЕМЉИ У РАЗВОЈУ
}

\author{
Omvir Gautam, Pooja Agrawal
}

Извод

Претежна брига у садашњем радном окружењу су погодности дневног боравка за парове са двоструком каријером у земљама у развоју попут Индије. Ово игра значајну улогу у импровизацији односа послодавац и запослени. Ова студија идентификује кључне факторе попут изостајања и задовољства послом међу паровима са двојинм каријерама према услугама дневног боравка које спонзоришу организације. Штавише, улога дечјих вртића која су спонзорисана од стране организације испитана је заједно са модераторима као што су пол и број деце. Коришћен је дескриптивни дизајн истраживања кроз употребу упитника који је самоадминистриран на узорку од 197 запослених из две државе Пуњаба, тј. Амритсар и Пуњаб, Индиа; како би се проценила улога модератора пола и броја деце у односу на организационо спонзорисане вртиће. Организационо спонзорисане погодности дневнеог смештаја према степену изостајања и задовољства послом су значајнр Организационо спонзорисане погодности дневног смештаја су позитивне новине за запослене, за послодавце у земљама у развоју попут Индије. Будућа истраживања могу се усмерити на импликације погодности организационо спонзорисаних вртића на дугорочно одржавање постојања организације.

Кључне речи: дневни боравак, организационо спонзорисано, задовољство послом, пол, модератор, број деце, изостајање

Barmby, T.A., Orme, C.D., \& Treble, J.G. (1991). Worker Truancy: An Analysis Using Micro Data. Economic Journal, 101 (405), 214-229.

Eisenberger, R., Fasolo, P., \& DavisLaMastro, V. (1990). Perceived Organizational Support And Employee Diligence, Commitment, And Innovation. Journal of Applied Psychology, 75 (1), 5159.

Ezra, M., \& Deckman, M. (1996). Balancing Work and Family Responsibilities: Flextime and Day Care in the Federal Government. Public Administration Review, 56 (2), 174-179.

Farrell, G. (1980). On site day care: The state of the art and models development. Albany, NY: Welfare Research Institute.

Field, A. P. (2005). Is the meta-analysis of correlation coefficients accurate when population correlations vary?. Psychological methods, 10(4), 444.

Fornell, C., \& Larcker, D. F. (1981). Structural equation models with unobservable variables and measurement error: Algebra and statistics.

Geurts, S., Kompier, M., \& Gründemann, R. (2000). Curing the Dutch disease? Sickness absence and work disability in the Netherlands. International Social Security Review, 53(4), 79-103.

Gimeno, D., Benavides, F.G., Amick, 
B.C., Benach, J., \& Msartinez, J.M. (2004). Psychosocial Factors and Work Related Sickness Absence among Permanent and Non-Permanent Employees. Journal Epidemiology Community Health, 58 (10), 870-876.

Goff, S.J., Mount, M.K., \& Jamison, R. (1990). Employer Supported Day Care, Work/Family Conflict, and Truancy: A Field Study. Personnel Psychology, 43 (4), 793809.

Gullekson, N.L., Griffeth, R., Vancouver, J.B., Kovner, C.T., \& Cohen, D. (2014). Vouching For Childcare Assistance with Two Quasi-Experimental Studies. Journal of Managerial Psychology, 29 (8), 994-1008.

Hair, J.F., Black, W.C., Babin, B.J., \& Anderson, R.E. (2010). Multivariate data analysis (7th ed.). Upper Saddle River, New Jersey: Pearson Education International.

Hester, S. B., \& Dickerson, K. G. (1984). Serving Dual-Career Families: Problem or Opportunity? Journal of Extension, 22, 2127.

Jha, P. (2004). Current Government Policies Towards Health, Education and Poverty Alleviation in India: An Evaluation. unpublished report.

Johns, G. (2003). How methodological diversity has improved our understanding of absenteeism from work. Human resource management review, 13(2), 157-184.

Keith, P. M., \& Schafer, R. B. (1980). Role strain and depression in two-job families. Family Relations, 483-488.

Kossek, E.E., \& Nichol, V. (1992).The Effects of On-Site Day Care on Employee Attitudes and Performance. Personnel Psychology, 45 (3), 485-509.

Leaker, D. (2008). Sickness absence from work in the UK. Economic \& Labour Market Review, 2(11), 18-22.

Meisenheimer, J.R. (1990). Employee
Absences in 1989: A New Look at Data from the CPS. Monthly Labor Review, 113 (8), 28-33.

Miller, T.I. (1984). The Effects of Employer-Sponsored Day Care on Employee Truancy, Turnover, Productivity, Recruitment or Job Satisfaction. Personnel Psychology, 37 (2), 277-289.

NICHD Early Child Care Research Network. (2002). Early Child Care and Children's Development Prior to School Entry: Results from the NICHD Study of Early Child Care. American Educational Research Journal, 39 (1), 133-164.

Nunnally, J. (1978) Psychometric Methods. 2nd Edition, McGraw-Hill, New York.

Perry, K. S. (1978). Survey and analysis of employer-sponsored day care in the US Unpublished doctoral dissertation. University of Wisconsin, Milwaukee.

Rapoport, R., \& Rapoport, R. N. (1969). The dual career family: A variant pattern and social change. Human relations, 22(1), 3-30.

Ratnasingam, P., Spitzmueller, C., King, W.R., Rubino, C., Luksyte, A., Matthews, R.A., \& Fisher, G.G. (2012). Can On-Site Child-Care have Detrimental Work Outcomes? Examining the Moderating Roles of Family Supportive Organization Perceptions and Child-Care Satisfaction. Journal of Occupational Health Psychology, 17 (4), 435-444.

Simons, R.L., Lorenz, F.O., Conger, R.D., $\& \mathrm{Wu}$, C.I. (1992). Support from Spouse as Mediator and Moderator of the Disruptive Influence of Economic Strain on Parenting. Child Development, 63 (5), 1282-1301.

Steers, R.M., \& Rhodes, S.R. (1978). Major Influences on Employee Attendance: A Process Model. Journal of Applied Psychology, 63 (4), 391-407.

Turner, W. C., Muck, R. D., Muck, R. J., 
Stephens, R. L., \& Sukumar, B. (2004). Cooccurring disorders in the adolescent mental health and substance abuse treatment systems. Journal of Psychoactive Drugs, 36(4), 455-462.

Youngblood, S.A., \& Chambers-Cook, K. (1984). Day Care Assistance can improve Employee Attitudes and Behavior. Personnel Administrator, 29 (2), 93-95. 